\title{
Taxonomic study of edible bivalve from selected division of Sarawak, Malaysia.
}

\begin{abstract}
The diversity of edible bivalve was conducted from August 2010 to July 2011 covering eight divisions i.e., Kuching, Sarikei, Sibu, Mukah, Bintulu, Miri, Limbang and Lawas of Sarawak, Malaysia. Samples were collected from native market and fishing village during the study period. All edible bivalves inhabit either in brackish or marine environment and comprised 19 species from 10 families namely Meretrix meretrix, M. lyrata, Paphia undulata, Circe scripta, Solen regularies, Solen lamarckii, Pharella acutidens, Amusium pleuronectes, Anadara granosa, Pholas orientalis, Gluconome virens, Placuna placenta, Crassotrea lugubris, Isognomon ephippium, Polymesoda erosa, P. bengalensis, P. expansa, Anadonta woodina and Pilsbryoconcha exilis. The diversity of edible bivalves was found highest in Kuching and Bintulu compared to other divisions studied in Sarawak. The bivalve species at Sarawak could have economic potentiality in terms of protein source, livelihoods of local tribes and economic value. Study suggests that if the high conservation and management of edible bivalve diversity could establish in the coastal and wetland area of Sarawak, a remarkable and vast economic return could achieve.
\end{abstract}

Keyword: Distribution; Economy; Edible bivalve; Habitat; Sarawak. 